\title{
Computers and Industrial Organization: Early Sources of 'Just in Time' Production in the Dutch Steel Industry
}

\author{
JAN VAN DEN ENDE
}

\begin{abstract}
This article focuses on the growth of production planning in the Dutch Hoogovens Steel Company. In response to market changes in the 1950 s, production facilities and capacity were enormously expanded, and a decentralized just-in-time system of production planning was developed. Punchedcard machines were introduced to process the necessary data. In spite of these efforts a control crisis emerged in the company, resulting in large order backlogs and long delivery times. In response, production planning was centralized and digital computers introduced.

This article will demonstrate that the choice of computing technologies was intimately related to the organization of production planning. Although the introduction of just-in-time systems is normally considered a consequence of the evolution of computing technology, in this case such a system appears to have contributed to the demand for digital computers. The question that will be posed is, to what extent do these views corroborate those expressed in James Beniger's book The Control Revolution?
\end{abstract}

$\mathrm{C}$ omputing is generally associated with the "third" service sector. For instance, banks and insurance companies are large data processing organizations. Furthermore, in the history of computing, the military and the field of science and technology are traditionally considered important applications of computing equipment. The information processing activities in the second, or industrial, sector have received far less attention. Nevertheless, in the course of this century, information processing activities within this sector have increased very significantly, creating a third sector within the second.

This article looks at these activities. It focuses on computing for production planning purposes at the Dutch Hoogovens Steel Company between 1924 and 1965. Production planning includes the programming and control of company production; it determines what is produced, when, and by which of the company's plants. It includes order entry, scheduling, progress control, and stock control. The aim of production planning is to maximize customer service while optimizing the use of production facilities and minimizing stocks.

Hoogovens was established in 1918, but actual production started in 1924. This article focuses on the period after the Second World War, when Hoogovens enlarged both production facilities and computing activities considerably. Separate production planning departments were established at each plant, which generated a lot of data processing facilities; as a consequence, Hoogovens was also an early and important user of computing equipment for production planning within the Netherlands. The company applied three methods of data processing: manual, punched-card machines, and the digital computer.
The central questions of this article are, why did demand at Hoogovens for computing technologies in production planning increase in the course of time, and why were specific technological choices made? In answering these questions, specific attention will be paid to the influence of wider societal changes. In this way the article aims at providing more insight into the background of digital computing's early success and the reasons for the rise of the information society.

The question will be posed whether the Hoogovens case corroborates the ideas of James Beniger in The Control Revolution. ${ }^{1}$ According to Beniger, the application of information technology, including the digital computer, was a response to a control crisis that appeared in the material processing system in the second half of the 19th century (and which continues to the present day). This system includes the production, transport, and sale of goods. According to him, a faster control system was required, a system not limited by human, animate, and natural kinetic power, but which relied on the inanimate power of steam.

In general Beniger can be criticized for several reasons: His concept of control is extremely broad, encompassing highly divergent activities (control of ships and control of companies, for example). Moreover, the demand for digital computers arose not only within organizations engaged in the material processing system, but also within government activities not directly related to this system. Nevertheless, the case of production planning at Hoogovens, to a certain extent, accords with Beniger's analysis. The increasing complexity and size of the production system required new means of managerial control. It appears that production planning was an impor- 
tant means of increasing control and that the growth and centralization of production planning was intimately related to the introduction of new computing equipment.

In this article I distinguish three periods:

1. 1924-1947, the creation of an integrated steel company;

2. 1947-1958, expansion of the company;

3. 1958-1965, centralization and automation.

In the first period an integrated steel company was established, including production facilities for sheets and plates. Also in this period data processing was performed manually if at all. In the second period Hoogovens extended production facilities with the production of steel strip; both production and production planning activities were expanded considerably. In addition, punched-card machines were introduced. In the third period a control crisis emerged within the company, resulting in the centralization of production planning. In this later period Hoogovens introduced digital computers.

To begin, a short, general explanation of the steel production process and the structure of steel works will be helpful.

\section{Creating an integrated steel works (1924-1947)}

Integration in the steel industry. Hoogovens Company was founded at a time when modern steel works were integrated companies, which meant that they included three production phases ${ }^{2-5}$ :

1. Iron making. Iron was produced from iron ore and coke in blast furnaces.

2. Steel making. Steel was produced from iron and scrap in steel-making plants. Steel is a type of iron with a low carbon content. Two main types of steelmaking processes were applied: In the Bessemer (and Thomas) process, air was blown over liquid iron in a converter; in the open-hearth process (also called the Siemens-Martin process), iron and scrap were heated for several hours. In both processes additions (lime, for instance) were made.

3. Production of intermediary steel products. This phase included rolling mills for plates, sheets, strip (sheet on coils), shapes, billets, bars and rods, and coating facilities, in which the steel products could be tinned, painted, and so forth.

Steel works were also normally engaged in processing byproducts such as gas (from the production of coke from coal), fertilizer (from the gas), and cement (from the blast furnace slag). Integrated steel companies were often located at good transport connections, for instance, at important canals. One reason for this was that high-quality iron ores from distant locations were used. Many steel companies were therefore located far from the coal mines, although they often still participated financially in coal mines in order to secure delivery.

The integration process had started in the United
States and Germany in the second half of the 19th century. The integration of production facilities had several purposes, the first technical, the second related to energy savings ${ }^{2,6}$ :

- The Bessemer (and Thomas) steel processes required the iron to be poured in liquid form into the steel converter.

- In the open-hearth steel-making process, using liquid iron was not necessary but did save the energy of

\section{In a later period a control crisis emerged within the company, result- ing in the centralization of production planning. In this period Hoogovens introduced digital computers.}

reheating. In an integrated steel company, the gas produced by the coke plants could also be used further on in the production process.

- Integration diminished transaction costs between factories.

- Integration facilitated increased quality standards, since quality could be monitored during the entire production cycle.

The integration process was stimulated by decreasing transport costs during industrialization (new railroads and canals) and the growing scale of steel production. By 1917,12 of the 26 largest iron and steel makers in the US owned a full range of mines, transportation facilities, blast furnaces, steel plants, and rolling mills. ${ }^{4}$ Integration generally remained limited to intermediary steel products such as plates and sheets. Only four of the 26 companies had integrated further to include finished products.

In England, integration remained very limited until the Second World War. Britain had been the world leader in iron production in the middle of the 19th century but had trailed behind since then. In suggesting reasons for this delayed integration, the literature mentions (1) the high quality of the British market system, which satisfactorily coordinated the activities of nonintegrated firms, and (2) British family-based managerial structures that hindered integration.? In England a large part of steel production was carried out in open-hearth plants in which iron could be used in cold form, and this may also have contributed to the lack of integration.

The Hoogovens Company. When Hoogovens was founded in 1918 , the company was intended to become a modern integrated steel works. ${ }^{8}$ Hoogovens was located on the Dutch coast, at the entrance of an important canal. However, budgetary limitations initially confined the new 
'Just in Time' Production

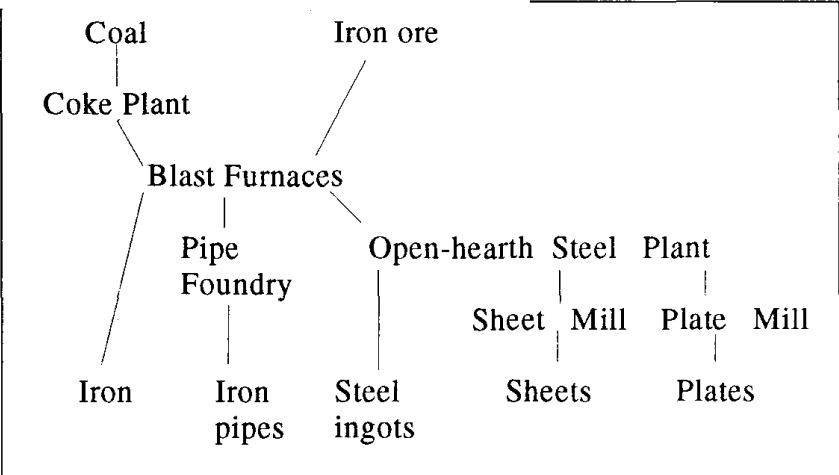

Figure 1. The production process, 1947.

company's production facilities to the production of iron and its by-products. The first blast furnace started production in 1924; the second and third followed in 1926 and 1930. The iron was cast in pigs in sand and later sold to other companies that processed it further into iron products and steel. The company operated on the international market: Most of the raw materials were imported, and more than 75 percent of the iron produced was exported.

From the mid-1930s onward, the company included more production phases. In 1935 a pipe foundry was built. In 1939 Hoogovens established its own steel plant, of the open-hearth type. This process produced higher quality steel than the alternative Bessemer (and Thomas) processes but at higher costs. Considerations concerning the supply of iron ore, the market for iron and steel products, and the desire for the Netherlands to have an independent steel supply led to the choice of this process. In 1941 mills were included in the company when

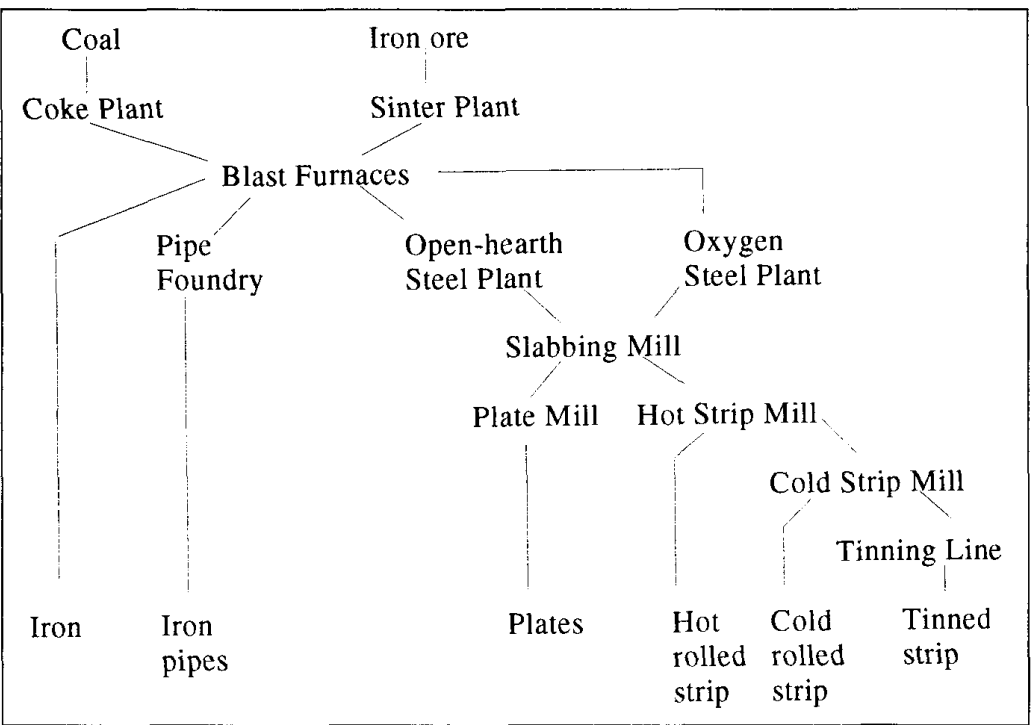

Figure 2. The steel-making process, 1958.
Hoogovens bought a sheet mill (Walserij Oost) from the Van Leer Barrel Industry, which had established the mill on the Hoogovens site in 1938. In 1939 Hoogovens began construction of a plate mill. Plates were used mostly in ship building. The factory was finished in 1943 but then dismantled and carried off by the German occupiers. The mill came back after the war and was rebuilt, finally starting production in 1947 . The resulting production process is summarized in Figure 1. In 1947 Hoogovens employed about 4,600 workers.

Manual data processing. Data processing and production planning were not very important before 1950 . Data was processed manually. An early example of manual data processing at Hoogovens, although not for production planning purposes, was given at a large exhibition on office organization held in Amsterdam in $1923 .{ }^{9}$ Employees of Hoogovens Company, which had yet to start production, explained in detail the control of inventory. Every purchase or use of materials or tools was accompanied by an appropriate accounting action, often using multiple forms. Punched-card machines were not yet used. They were introduced in 1916 in the Netherlands ${ }^{10}$ and were applied widely beginning in the $1920 \mathrm{~s}$; however, as we shall see, their introduction at Hoogovens would have to wait until 1956.

Production planning was performed by the plant management. Later (in the sheet and plate mills) their administrative staff assisted. The historian of labor relations at Hoogovens, M. van Elteren, " notes that around 1950 in the sheet mill, about 10 administrative staff were engaged in planning and preparing the work. No specific accounts of production planning in this factory during the previous period are available, but production planning activities would have been less important because the sheet mill initially had only one main customer, the Van Leer Barrel Industry.

\section{Growth of production plan- ning (1947-1958)}

The Breedband Company. The late 1940 s and the 1950 s were boom years in the steel industry. A lot of steel was used in cars, household appliances, furniture, food canning, construction, and weaponry. For several of these purposes, many different varieties of steel, some of them of high quality, were required. For instance, the auto industry required so-called deep-drawing steel, which had to meet high requirements.

At Hoogovens, new production facilities were established, with 
the company aiming mainly at the export market, particularly after the start of the European Community for Coal and Steel in 1953. In 1952 a new company for the production of wide strip, the Strip Mills Company ("Breedband Company"), was established with government support and Marshall Plan aid funds. Wide strip was used in the auto industry and in food canning. The company had two mills, a hot strip mill and a cold strip mill, and a tinning line. Between the two mills the strip had to pass through a pickling line. A slabbing mill was built to convert the ingots coming from the steel plant into slabs in preparation for the mills. The Breedband Company took over production of the sheet mill, which was closed in 1953. The capacity for steel production was enlarged by establishing new and larger steel plants.

In 1958 Hoogovens introduced the oxygen steel-making process. This process, developed in Austria in 1939, was an improvement on the Bessemer process and meant that higher quality steel could be produced in a relatively simple plant. Steel production increased rapidly: In 1947, 100,000 tons were produced, and in 1958 the 1-million-ton mark was passed. The number of workers increased from about 4,600 in 1947 to 10,300 in 1958 .

Production on order. In response to the growing complexity of the company (see Figure 2), Hoogovens extended its cost accounting and production planning activities. Cost accounting was improved by the introduction of the budget system in 1950, when every plant was given its own financial budget for expenditures. Internal services were settled between plants. The aim of the system was to decentralize financial responsibilities within the company and to enhance the awareness of efficiency. To administer the system, cost accounting sections were established in every plant.

More important still was the extension of production planning activities. One reason for this was that the company traditionally had a system of production to order. A large part of production was carried out for specific orders. With the inclusion of more intermediary steel products in the production process, and higher and more diverse quality requirements, the number of different orders increased. In 1955 the plate mill met about 200 orders (consisting of about 3,000 entries) for 40,000 plates each month. The Breedband Company produced about 15,000 coils of strip per month in the same period.

To control the production of all these different orders, Hoogovens operated a kind of "just in time" production planning system. In many industries such systems have since become a popular method of minimizing stock and increasing the selection of end products. The crux of the system was that every factory sent orders to factories upstream in the production cycle. By this means, clients' orders were combined into increasingly larger orders, because plants at the start of the production cycle produced larger quantities of products in one batch than factories further down the line. At the same time that plants ordered materials from a plant higher in the cycle, they prepared a work schedule for processing when the material arrived. As we shall see, these work schedules had to meet specific technical requirements.

Here, at a more detailed level, is how planning functioned. The Sales Department sent orders to the relevant mills after the Quality Department had added the product specifications. At the mills the orders were scheduled for a specific week and combined with other orders with the same, or similar, quality requirements. The mill administrators placed these combined orders at the slabbing mill, the next plant up in the production cycle. There the

\section{The combined production planning departments of Breedband accounted for 44 employees in 1954. In 1956 this number had increased to 60 .}

process was repeated, resulting in orders large enough for the steel-making plants. Losses of material, which depended on the size and quality of the product, were taken into account. It was also anticipated that a steel batch would occasionally fail to meet quality requirements and would have to be rejected. When the steel was delivered, the process was reversed - every plant split the order into smaller ones. Toward the end of the production cycle, this process became very complicated.

In the plate mill, which as we saw started production in 1947 , ingots were rolled into plates. The ingots were heated, rolled into plates of the desired width and thickness, and subsequently cut into plates of the desired length. Production planning was carried out by the factory's administration. It combined plate orders into larger plates that could be rolled. Weekly plans were made for these plates, the sizes of the slabs needed were calculated, and, if they were not available from stock, these slabs were ordered from the slabbing mill. The administration also prepared daily production plans. These had to meet an important technical condition: Production was performed in cycles, between which the rolls had to be changed. One cycle lasted about 16 hours. Within a cycle the plates had to be rolled from wide to narrow, otherwise uneven wear in the rollers would result in uneven plate thickness. The administration also reorganized the production program after anomalies, for instance, if plates did not meet quality requirements. The plates were then reprocessed or rejected. In the latter case new plates had to be produced and a new use for the rejected products sought. In both cases, adapting the production program was a very laborious process.

The part of the administration engaged in production planning in 1954 comprised about 40 people. These were divided into a number of subunits: order administration ( 3 staff), rolling schedules (6), slab stocks (2), quality control (2), semi-finished products (5), plates administration (3), delivery (2), typing room (4), reports (5), and time administration (4). The administration also included a cost 


\section{'Just in Time' Production}

accounting section (6 staff) responsible for the financial budgets.

In the Breedband Company the situation was different, because here each plant (hot strip mill, cold strip mill, tinning line) had separate production planning, production control, and cost accounting sections. The production planning sections performed the production programming; the production control sections recorded data on the production process. The Central Production Planning Department of the Breedband Company supervised and coordinated the activities of the decentralized production planning sections. The combined production planning departments of Breedband accounted for 44 employees in 1954. In 1956 this number had increased to 60 .

In the Breedband Company, production planning was even more laborious than in the plate mill. The process was more complicated because the strip metal could run through successive plants, from the hot strip mill to the cold strip mill and then to the tinning line. Each plant involved different technical requirements in production planning. For example:

- In each mill, as in the plate mill, production was performed in cycles within which the coils of strip had to be rolled from wide to narrow.

- In the cold strip mill, rolling adjustments for changes in coil width of more than $4 \mathrm{~mm}$ were laborious. In general, the number of mill adjustments had to be minimized, as each adjustment could lower the quality of the first products milled after such adjustment.

- In the hot strip mill, the rolling had to be carried out in specific orders of thickness that depended on the quality of the steel.

- In the cold strip mill, the same type of strip was preferably processed for a number of consecutive days.

- In the annealing furnace (part of the cold strip mill) it was most efficient to combine only coils of the same quality.

Between the hot strip mill and the cold strip mill the coils had to pass through the pickling line with yet other requirements. Because of the different requirements of the various installations, stockpiles were formed between them, but these had to be minimized. A 1958 report explains how the production planning departments worked to fulfill all these requirements. Complicated data processing systems, using many different forms, were needed for production planning. When production errors occurred, planning changes were needed, and they were extremely laborious.

Apart from the decentralized production planning departments, Hoogovens also had a Central Production Planning Department. Its task was limited to overseeing the division of steel from the steel plants between the plate mill and the Breedband Company, and it prepared the quarterly and yearly planning surveys for management.

Punched-card machines. Before 1956 the only mechanical aids to production planning had been special slide rules and desk calculating machines used for specific tasks, such as calculating the weight of a plate that could be produced from a slab or preparing work schedules. Punched-card machines had been on the Dutch market since the 1920 s and were in wide use. Not only did the growth of data processing activities in the 1950s form an incentive for Hoogovens to introduce punched-card machines, but also the need for each factory to do a great deal of "multiple processing" was a factor. Data had to be processed several times for different purposes: for production planning of the factory itself, to place orders at factories upstream in the production cycle, and for the Quality Department, Sales Department, and accounting departments. The punched-card method was particularly advantageous in such situations because although the initial punching was relatively time-consuming work, it was more than compensated for when data had to be processed many times. Hoogovens chose French-made Bull machines and first installed them in 1956. It was a modest installation: one sorting machine, one tabulator, a reproducer (to copy cards), one collator (to collate presorted stacks of cards), and a calculating punched-card machine - the Calcul.

A new Data Processing Department was set up to operate the machines and produce the original data cards - a job performed largely by females in this department, though in the plants men often performed the punching labor. These men sometimes worked in shifts, as did many other plant workers. In time, the number of punched-card machines grew. In 1957 an electronic "Gamma" machine was purchased for more complicated calculations. It had a small memory - 84 digits - and had to be connected to other punched-card machines for basic operation. In 1958, 3.5 million cards were used, and by 1959 , three years after its introduction, 1 million guilders had been invested in punched-card equipment. The Data Processing Department then employed 38 people.

The department provided services for three companies: Hoogovens, the Breedband Company, and Mekog (the associated fertilizer company). Production planning formed the most important application of the punchedcard machines; in 1960 more than 60 percent of the Data Processing Department's work was reported to consist of daily production planning. ${ }^{12}$ Punched cards were used primarily to record data, while the actual planning activities were performed mainly by hand.

Other important applications of the punched-card method were cost accounting, statistical quality control, and sales and shipment statistics. Later on, in 1961, the payroll was also transferred to punched-card machines. It is interesting to note that the procedures used on the punched-card machines were described in flowcharts, just as they would be later in the computer era.

Strict organization. Punched-card machines were first used for production planning in the plate mill. This application was attractive not only because of the increased scale of production planning activities but also because much of the data had to be used several times for different purposes. Moreover, the Hoogovens management 
expected that the punched-card system would improve managerial control over the operations, for two reasons: First, more information on the progress of orders and on rejected plates could be produced with little extra cost; second, it was expected that this method would stimulate stricter procedures and registration:

... the strict organization required and the compelling uniformity of the accounting procedures will give improved assurance that managerial instructions will indeed be executed in the manner and at the time prescribed. ${ }^{13}$

We will see that the control issue would become more important toward the end of the $1950 \mathrm{~s}$.

Operation of the punched-card method for production planning of the plate mill was reasonably straightforward. For each slab and plate, a card was punched in which not only the size and quality were recorded but also technical data on the production process. Scheduling was performed mechanically with the use of these cards. The punched-card machines automatically produced cards to record errors and for stock control. These cards accompanied the plates through the plant (Figure 3). The Gamma electronic punched-card machine was used for calculating the weights of the plates in the plate mill, given their dimensions and densities.

Not all steps in production planning could be performed using the punched cards. For example, combining ordered plates into plates that could be rolled remained a manual skill; for this procedure, experience and intuition remained important. Moreover, in spite of the existence of the punched-card system, informal factors still influenced production planning. One of the assistant managers from that period (later a general manager), W. Singer, relates that it was not unusual for the head of production planning to go around the plate mill personally distributing cigars to the employees, trying to speed up completion of a specific order. ${ }^{14}$

Objections. In the Breedband Company the punchedcard system was introduced far more slowly. Initially only a few cost accounting procedures were transferred to the system, and some data on the production process was punched on cards for statistical analyses by the Quality Department. Production planning was not transferred to punched cards until 1961. The delay was caused by objections within the Breedband Company to this method:

- The location of the machines was seen as a problem; they were located in the main office building far

from the installations. On the other hand, the Breedband Company's administrative workload did not justify the possession of machines by this company alone.

- It was expected that mechanization would require at least some employees in the production planning departments to start work earlier than usual, at 6:00 a.m. If they didn't, certain figures - for instance, the daily production figures - would become available later than before.

- The plant would have to be sure that the machines were available at certain hours of the day, for instance, early in the morning. This was a problem because the machines were shared by different plants.

- Mechanization would diminish planning flexibility. Sometimes the daily working plans had to be changed within less than 15 minutes. This would be difficult in a punched-card system, and the delay could cause losses in production.

- Some of the accounting procedures had already been mechanized, on bookkeeping machines.

It was also noted that mechanization would stimulate the centralization of production planning within the firm.

\section{Combating a control crisis (1958-1965)}

Continued growth. After 1958 the company continued to grow, particularly by extending the existing range of production installations. As a consequence of company growth and the large staff turnover at Hoogovens (almost 40 percent of the personnel between 1958 and 1961), many new workers were needed. Recruitment was hin- 
dered by a tight labor market and the strict wage policy imposed by the Dutch government. ${ }^{15}$ Workers were therefore recruited from Mediterranean countries: Italy $(1,100)$ and Spain $(1,400) .{ }^{11}$ Because of the growth of administrative activities, the number of clerical staff in the company increased faster than the number of blue-collar workers (see Table 1).

Lack of coordination. Despite all efforts to organize production in an efficient and rigorous way, toward the end of the 1950 s a control crisis emerged at Hoogovens. The production process became increasingly chaotic, resulting in long delays in the delivery of orders. The situation was caused by both the growing complexity of the company and the growth of production. The number of different orders increased sharply, while the execution of each order became more complex. The organization could not handle the situation. O.H.A. van Royen, who worked in the Quality Department at the time, and who would become chairman of the management of Hoogovens Company in 1988, remarked:

Hoogovens lacked an unequivocal organization. ... There was a lot of disagreement, about fields of competence, what this or that person was allowed or not allowed to do. A typical situation for a company in its pioneering phase. ${ }^{16}$

According to Van Royen, steel companies abroad were encountering the same problems during this period. Van Royen's views are confirmed by the recent study by Dankers and Verheul on the Hoogovens Company, ${ }^{17}$ which states that "Frictions and resistances originated between the different departments, caused by inefficient meetings, deteriorating communication and indistinct task divisions." 18 They also impute the problems to the pioneering phase, in which the company still found itself. The retirement, in 1958, of General Manager A.H. van Ingen Housz, who had held an important position since the inception of Hoogovens and who now became a member of the company's supervisory board, helped to end the pioneering phase in management. Furthermore, in the personnel area, the human relations approach, which had meshed so well with the close community spirit at Hoogovens, was adapted to introduce the so-called "integral organization" philosophy. ${ }^{19}$ According to this idea, workers' awareness of their place in the organization had
Table 2. The number of employees of the Data Processing Department, the number of systems analysts of the Department for Office Organization ( $\mathrm{AO}$ ), and the number of employees of the Department of Automation and Information Systems (AIS). The number of punched-card typists appears in parentheses.

\begin{tabular}{llll}
\hline Year & Data Proc. Dept. & AO & AIS \\
\hline 1959 & 38 & & \\
1962 & $82(33)$ & 17 & \\
1966 & $164(55)$ & 40 & \\
1970 & & & 400 \\
\hline
\end{tabular}

to be increased. The Personnel Department started to promote task separation and planning.

Still more important, however, was the reorganization of production planning. In 1958 Hoogovens' own Business Organization Department began a study of production planning, though this did not immediately lead to practical results. According to Van Royen the reason for this was that the department lacked authority within the company. Nevertheless, the discussion continued; members of staff visited steel companies in the US, and working groups were set up for each group of plants at Hoogovens. Finally, in 1961, the international consultancy firm Booz, Allen and Hamilton International Inc. (Bahint) was contracted to advise on the place and function of production planning within Hoogovens. This consulting firm had accumulated experience in production planning in steel industries all over the world.

In its report, "Recommendations for PPC" (production planning and control) ${ }^{20}$ the consultants advised centralizing production planning activities. The report provides an idea about the shortcomings of Hoogovens' production planning at that time: It criticized its inflexibility and its orientation toward the requirements of the production process rather than those of the customer - an orientation that resulted in a large order backlog. This method gave the production units the flexibility to develop more efficient production schedules, but it was a disadvantage to the customers, since it delayed delivery. According to a small inquiry, more than half of the orders were delivered late - the majority more than a month late. The report also criticized management's lack of information on company performance, such as missed promises, order backlogs, late schedules, free capacity, inventories, and so forth. The advice was to improve the situation by establishing a new Central Production Planning Department in which Hoogovens Company would integrate planning and control. This department would report directly to the general manager and not to the management of the plants or to the sales director.

Although the figures on order backlogs were criticized by the management of the plants involved, the report confirms that a "control crisis" had emerged within the company. Production did not yet function adequately; it was organized in such a way as to optimize production efficiency, but customer requirements suffered. 
According to Bahint, the new Central Production Planning Department would have to manage the affairs of the existing production planning and production control departments, so these two latter groups had to be taken out of the administration. This centralization would improve communication between the sales office and the plants. The report describes the function of the production planning departments as "... providing an objective and effective link between sales and production." 21 "Objective" was intended to mean "... not subjected to the desires of either production or sales to the exclusion of the other." ${ }^{21}$ It meant that the authority of the separate plant managements would diminish, a view confirmed by Assistant Manager Singer.

Another reason for centralizing production planning was the availability of the digital computer. Engineers and scientists had been developing digital computers in several research laboratories in the Netherlands since the end of the 1940s. The first of these machines became available around 1953, and computers of foreign origin had been employed since 1955. The report stated that centralization would facilitate the application of this technology at Hoogovens.

The management of Hoogovens decided to take the committee's advice; the new department was established as early as 1961. O.H.A. van Royen of the Quality Department was appointed as its head. Part of the existing production planning staff was transferred to the new department, which soon numbered about 170 people. Orders were sent from this department to the various plants on a daily basis.

Digital computers. In 1961 Hoogovens acquired its first digital computer. J.F. ten Doesschate, general manager of the Hoogovens Company, had chaired a committee of the National Society of Efficiency Experts (NIVE) that discussed the social consequences of digital computers. Hoogovens bought a secondhand Gamma AET, manufactured by the French company Bull, from the aircraft company Fokker. The machine was installed in, and managed by, the Data Processing Department, where it augmented rather than replaced the punched-card equipment. Initially it was used for research purposes, mainly by the Operational Research Group of the research laboratory. From 1962 onward, it was used predominantly for production planning and payroll.

In 1964 Hoogovens bought a larger computer system for data processing, an IBM 1410, for 1.4 million guilders. It was a transistorized computer with a disk memory. In spite of the high price, it was considered more economical than adding punched-card equipment and personnel, which were becoming increasingly expensive because of the rising cost of equipment and salaries. At that time the Data Processing Department still operated a large number of punched-card machines: 10 sorters, five reproducers, seven tabulators, and so forth. In 1965 the Gamma AET was operated in two shifts and the IBM 1410 in three shifts.

The number of employees in the Data Processing Department grew considerably (see Table 2). In the
Department for Office Organization (Administratieve Organisatie, or $\mathrm{AO}$ ) a growing number of systems analysts converted the manual data-processing procedures for punched-card machines or for the computer. In 1966 these two groups were merged into the Department for Automation and Information Systems (AIS). Its budget amounted to 6 million guilders per year, including the cost

\section{By 1964 the company had dropped any remaining reservations about the computer.}

of the machines. By 1970 the budget of the AIS Department had grown to 13 million guilders a year (including hardware), and the department had 400 employees. At that time Hoogovens switched their supplier of computing equipment for data processing from IBM to $\mathrm{CDC}$ (Control Data Corporation).

Automation of production planning. Production planning was an important application of the Hoogovens computers. A growing volume of data had to be processed for production planning, and in the Central Production Planning Department larger series of data processing operations had to be performed, concerning production in different plants. The computer was particularly suited to performing such large series of operations, selecting, if necessary, specific operations according to interim results.

The introduction of digital computers was further stimulated by the rising wages of clerical employees in the early 1960 s (a 50 percent increase for specific staff groups between 1958 and 1964). One might wonder if the conception of the computer as a giant brain - quite a popular idea in the $1950 \mathrm{~s}$ - also encouraged its application for production planning, since this suggested that the machine was particularly appropriate for these purposes. However, this is unlikely; the managers of Hoogovens involved in production planning and automation had more definite information about the capabilities of digital computers than just this metaphoric image.

Several steps in the production planning procedures of the plate mill were programmed on the Gamma AET computer. Computer programs were developed to control the order files, to determine which slabs were required, and to prepare the rolling schedule. Some procedures were left to be done by hand, such as checking the card files for the stock availability of slabs and combining plates into slabs. The Breedband Company, again, was slower to automate production planning procedures. As we saw, the company did not apply punched-card machinery before 1961. Its management also initially rejected the use of the digital computer for production planning because knowledge of the production process wasn't considered explicit enough to formalize the procedures. 


\section{'Just in Time' Production}

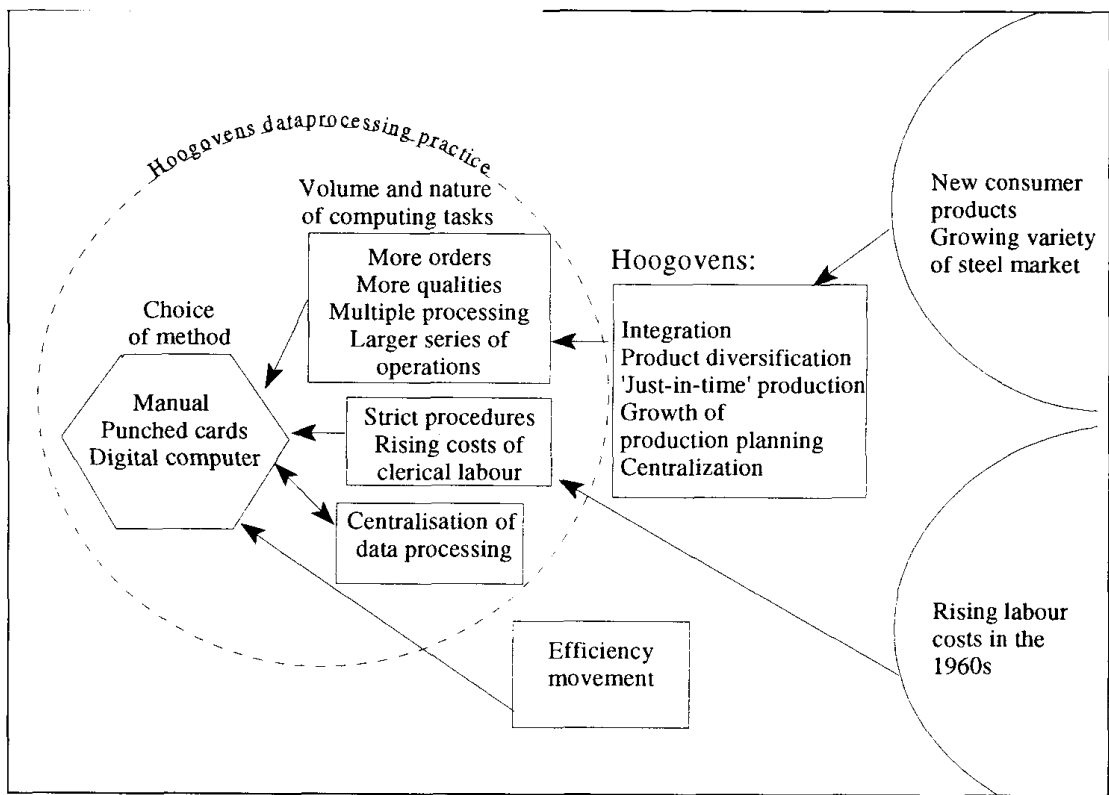

Figure 4. A number of important contextual factors affected the choice of computing method for data processing at Hoogovens.

Nevertheless, from 1961 onward, production planning procedures were gradually mechanized on punched-card machines and on the Gamma AET. After introduction of the IBM 1410, the automation of production planning at the Breedband Company was accelerated. A statement from the head of the Department for Office Organization indicates that the need for increased control explicitly stimulated the introduction of the computer for planning:

In the next few years production bottlenecks will increasingly appear at Breedband. These will concern production capacities, guarantees for reliable and short delivery times, quality control, optimization of intermediary and final stocks and the control of costs (and profits). Without a mechanized information system, the causes of and the relations between these problems can only be analyzed to a limited extent; the possibilities of control can also then only be utilized to a limited extent. ${ }^{21}$

By 1964 the company had dropped any remaining reservations about the computer. The complexity of production planning even led some staff members to consider it impossible to perform the planning by hand:

The requirements concerning assortment, quality, etc., generate such a complicated pattern of options that a human being can no longer be considered capable of making adequate choices or taking adequate decisions. ${ }^{22}$

However, production planning made heavy demands on computer reliability. For that reason a second IBM 1410 was leased in 1966 to diminish planning vulnerability. During the preceding period, the first IBM 1410 had failed once or twice a month for over four hours. During failures of such length, changes in manual procedures had to be made. Moreover, the growing workload also required expansion of computing capacity. Hoogovens has continued to employ two computers in parallel, for the sake of reliability, ever since - not only in planning, but in other applications as well.

\section{Conclusions}

It is clear that the volume of production planning activities increased considerably between 1924 and 1965 , particularly after the Second World War. The main reasons were the increasing size and complexity of the company, which in turn were a response to technological developments in steel production and to the growth and diversification of the steel market. The automobile industry in particular required high-quality steel products. The Hoogovens Company integrated more production phases, and to maintain the traditional system of production on order, the company introduced a type of just-intime production planning.

As a consequence of the growing complexity of this production system, toward the end of the 1950s a control crisis emerged within the company. It resulted in a growing backlog of orders, and failures of internal communication. In response, production planning was centralized, which entailed a further step in the internal integration of the company. The different plants, already under common financial, personnel, and executive management, were now subordinated to a central operational management. Authority decreased for plant managers and increased at the company management level. The centralization was an attempt to solve communication problems: The Centralized Production Planning Department served as a link between the Sales Department, the Quality Department, and the management of the various plants. It exchanged information both vertically (top-down, bottom-up) and horizontally (lateral, between departments at the same or adjacent levels). Figure 4 shows some of the factors affecting the choice of data processing methods at Hoogovens.

The growth and centralization of production planning was accompanied by a growing volume of data processing tasks and a change in their nature. As the spectrum of product quality levels grew, production planning depart- 
ments had to process more information about different orders. They often had to process the data a number of times (multiple counting) for different purposes or for other plants and departments. The centralization of production planning meant that the information became more complex. In the decentralized environment, the administration of each plant performed a limited number of operations on the incoming data (referring to incoming orders). This resulted in orders for plants upstream in the production cycle and in work schedules. The centralized department controlled a longer series of production phases and therefore performed a longer series of operations on data relevant to the process.

The computing methods for production planning accorded with the growing volume and changing nature of data processing. Three methods were applied in the course of time: the manual method (1924), punched-card machines (1956), and the digital computer (1962). Punched-card machines were particularly advantageous compared with manual computing for multiple processing. For instance, the administrations of the plants, the Quality Department, and the Statistics Department often used the same data, each for different purposes. However, punched-card machines also had important disadvantages. Most important was the required centralization of data processing at a distance from some of the factories, which caused transport problems and capacity problems when different plants needed the machines at the same time. For these reasons, the Breedband Company long refrained from introducing the punched-card method. Not only control problems within the company but also the centralization of data processing formed a stimulus for the centralization of production planning, since this would solve the transport problems.

The centralization of production planning in turn facilitated the use of digital computers. The series of operations on data became larger, and digital computers were particularly suited to performing more complex data operations. Nevertheless, if production planning had not been centralized, Hoogovens might still have introduced largescale digital computers for production planning purposes, though at a later date, for digital computers had the disadvantage of requiring specialized knowledge.

$\mathrm{T}$ he mechanization and automation of production planning have therefore to be considered principally as responses to the growing complexity of the production process, and they were intimately related to the growth and centralization of production planning. In the introduction I mentioned the work of J. Beniger, who considers information technology as serving control purposes, with emphasis on increasing the speed of control. The case of production planning at Hoogovens demonstrates that the application of new computing technologies in production planning not only aided management control over the different plants, but also forced them to solve communication problems between these plants and other departments. This means that these technologies cannot be seen simply as control machines, as Beniger claims; they are also communication devices. Moreover, they did not pri- marily increase speed: For instance, punched-card machines were often slower than manual data processing, particularly because cards had to be transported. The most important feature of the new equipment was its capacity to perform large volumes of complicated data processing. Complexity, not speed, was the primary reason for its introduction.

\section{Acknowledgments}

I would like to thank those who agreed to be interviewed for this article. This includes several employees and former employees of Hoogovens who participated in production planning or data processing during the period of this study, or who held managerial positions during that period: S. Kramer, D.G. Nijman, P. van de Oordt, O.H.A. van Royen, and W. Singer. I also thank H. Broekhuis, J. van Wijngaarden, and M. van Overveld of the Hoogovens Company for their assistance. Extensive use was made of the Hoogovens Archives. Thanks also to Martin Campbell-Kelly, who offered encouraging comments on prior versions of the manuscript.

\section{References}

1. J.R. Beniger, The Control Revolution, Technological and Economic Origins of the Information Society, Harvard Univ. Press, Cambridge, Mass., 1986.

2. P. Temin, Iron and Steel in Nineteenth-Century America, An Economic Inquiry, MIT, Cambridge, Mass., 1964, p. 190.

3. D.S. Landes, The Unbound Prometheus, Technological Change and Indusirial Development in Western Europe from 1750 to the Present, Cambridge U.P., London, 1969.

4. A.D. Chandler, The Visible Hand, The Managerial Revolution in American Business, Belknap, Harvard Univ. Press, Cambridge, Mass., 1977.

5. A.D. Chandler, Scale and Scope: The Dynamics of Industrial Capitalism, Belknap, Harvard Univ. Press, Cambridge, Mass., 1990

6. J. Kocka, "The Rise of the Modern Industrial Enterprise in Germany," Managerial Hierarchies, A.D. Chandler and H. Daems, eds., Harvard Univ. Press, Cambridge, Mass., 1980.

7. K. Warren, The British Iron and Steel Sheet Industry since 1840, An Economic Geography, Bell, London, 1970.

8. J. de Vries, Hoogovens IJmuiden 1918-1968, Ontstaan en Groei van een Basisindustrie, Hoogovens, IJmuiden, 1968.

9. "N.V. Koninklijke Nederlandsche Hoogovens en Staalfabrieken, Velsen. Inkoop- en Magazijndienst van de Hulpmiddelen voor het Bedrijf en der Materialen voor Onderhoud en Nieuwbouw," Tentoonstelling op het Gebied van de Openbare en Particuliere Bedriffsadministratie, Vol. 1, Muusses, Purmerend, 1926-1927, pp. 135-142.

10. J. van den Ende, "The Number Factory: Punched-Card Machines at the Dutch Central Bureau of Statistics," IEEE Annals History of Computing, Vol. 16, No. 3, 1994, pp. 15-24.

11. M.C.M. van Elteren, Staal en Arbeid, two volumes, Brill, Leiden, 1986.

12. W. Veldhuis and J. van Zanden, "De Automatisering der 


\section{'Just in Time' Production}

Informatie-verwerking," Tijdschrift voor Efficiency en Documentatie, Vol. 32, No. 12, 1962, pp. 713-716.

13. "de vereiste strakke organisatie en de dwingende uniformiteit van werkmethode geven de leiding meer zekerheid, dat gegeven instructies volgens de oorspronkelijke opzet en op de vastgestelde tijd worden uitgevoerd," Mechanisatie van de Administratieve Werkzaamheden bij de Samenwerkende Ondernemingen, Sept. 20, 1955, Hoogovens Archive, ds. 072, ra 1316, p. 2.

14. W. Singer, interview, March 3, 1992.

15. J.P. Windmuller and C. de Galan, Arbeidsverhoudingen in Nederland, Vol. 2, Aula, Het Spectrum, Utrecht, 1977.

16. "In die tijd was er geen eenduidige organisatie. ... Er waren ontzettend veel strijdpunten bij Hoogovens, bevoegdheden, terreinen, wat mag hij doen, wat mag hij niet doen. Het is typerend voor een bedrijf in de pioniersfase," O.H.A. van Royen, interview, Nov. 15, 1993.

17. J.J. Dankers and J. Verheul, Hoogovens 1945-1993, Van Staalbedrijf tot Twee-metalenconcern, SDU, Den Haag, 1993.

18. "Tussen de verschillende afdelingen ontstonden daardoor wrijvingen en weerstanden die het gevolg waren van inefficiënt vergaderen, tekortschietende communicatie en een onduidelijke taakafbakening," J.J. Dankers and J. Verheul (1994), Hoogovens, [17] chapter 2.

19. "integrale bedrijfsvoering," J.J. Dankers and J. Verheul (1994), Hoogovens, [17]

20. Booz, Allen and Hamilton Int'l Inc., Recommendations for Production Planning and Control, K.N.H.S. and Affiliated Companies, June 1961, Hoogovens Archive.

21. "De komende jaren zullen bij de produktie in Breedband in toenemende mate knelpunten gaan optreden. Deze liggen op het gebied van produktiecapaciteiten, het realiseren van betrouwbare, korte levertijden, de kwaliteitsbeheersing, het optimaliseren van kosten (o.a. rendementen). Zonder een gemechaniseerde informatieverwerking kunnen deze problemen zowel in hun oorzaken als onderlinge verbanden slechts in een beperkte mate worden geanalyseerd: demogelijkheden van besturen en beheersen kunnen dan eveneens slechts matig worden benut,"Van Zanden, Werkplan Administratieve Organisatie 1965, Dec. 1964 Hoogovens Archive, ds. 713.4, ra 1046.

22. "Door assortimentseisen, kwaliteitseisen etc. ontstaat een dermate ingewikkeld patroon van keuzemogelijkheden dat het menselijk organisme niet meer in staat geacht kan worden adequate keuzen te doen c.q. beslissingen te nemen," Samenvatting van een Drietal Besprekingen tussen Ap. Veh en Mak, 1964, Hoogovens Archive, ds. 07-1.

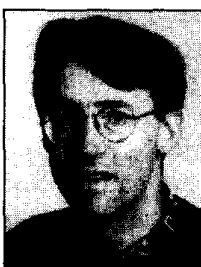

Jan van den Ende is a Dutch mathematical engineer and has studied comparative philosophy for some years. He is a univer sity lecturer in the History of Technology Unit and in the Technology Assessmen Unit of the Delft University of Technology, the Netherlands. In cooperation with Professor A. Nijholt in computer science, he published a comprehensive textbook on the history of computing and on the social responsibility of computer scientists (Geschiedenis van de rekenkunst, in Dutch). In 1994 he obtained his doctorate with a thesis on the history of computing in the Netherlands (The Turn of the Tide. Computerization in Dutch Society, 1900-1965, Delft University Press).

The author's address is History of Technology Unit, Delft University of Technology, De Vries van Heystplantsoen 2 2628 RZ Delft, the Netherlands; phone 31.15.78.3706, fax 31.15.78.3177, e-mail JvandenEnde@wtm.tudelft.nl. 